\title{
Pendampingan Manajemen Keuangan Bank Sampah “Alam Lestari” Dalam Menangani Permasalahan Sampah Di Kelurahan Gebang, Masaran, Sragen
}

\author{
Septiana Novita Dewi ${ }^{1}$, Aris Tri Haryanto ${ }^{2}$, Endang Brotojoyo ${ }^{3}$ \\ Dosen Sekolah Tinggi Ilmu Ekonomi AUB Surakarta \\ Email: Septianadewi25@yahoo.co.id ${ }^{1}$, arisharyanto26@yahoo.co.id ${ }^{2}$
}

\begin{abstract}
Abstrak
Kelurahan Gebang baru saja membuka kegiatan bank sampah yang diberi nama "Bank Sampah Alam Lestari" yang didirikan pada tanggal 23 Februari 2020 yang diketuai oleh Ibu Sri Supadmi dan dibantu dengan penduduk lainnya yang tinggal di desa Ngasinan Etan. Hal ini dilakukan dengan tujuan agar sampah-sampah penduduk dapat dikelola dengan baik dengan tujuan masyarakat selalu menjaga kebersihan. Selain itu dibentuknya bank sampah bertujuan untuk membantu masyarakat desa Gebang khususnya penduduk di desa Ngasinan Etan dapat menabung dari hasil sampah-sampah yang telah dikumpulkan, yang nantinya akan diambil oleh pengepul sampah. Karena bank sampah "Alam Lestari” di desa Ngasinan Etan baru saja dibentuk, maka diperlukannya pendampingan-pendampingan dalam mengelola manajemen bank sampah. Hal ini bisa dilihat dari cara pencatatan keuangan atau perhitungan sampah-sampah yang telah dikumpulkan, memberikan buku tabungan kepada masyarakat, serta bagaimana cara mencatat kas masuk dank as keluar. Selain itu dengan adanya panitia yang tergolong masih baru, sehingga masih banyak belajar dan pendampingan khususnya dari segi akademik, dalam hal ini peran perguruan tinggi. Dengan adanya permasalahan tersebut, maka Tim Pengabdian Kepada Masyarakat bermaksud melakukan kegiatan pengabdian agar sedikit bisa membantu dalam pengelolaan manajemen bank sampah "Alam Lestari". Hasil kegiatan pengabdian kepada masyarakat ini diharapkan mampu menghasilkan satu karya ilmiah berupa jurnal Pengabdian Kepada Masyarakat.
\end{abstract}

Kata Kunci :Manajemen Bank Sampah, Kelurahan Gebang

\section{PENDAHULUAN}

Sampah merupakan produk yang dihasilkan oleh manusia yang diperoleh dari kegiatan-kegiatan sehari-hari yang merupakan barang yang sudah tidak digunakan. Banyaknya tumpukan sampah dimasyarakat, menjadi permasalahan tersendiri bagi masyarakat luas. Selain membuat pandangan kelihatan kumuh, sampah juga mampu menghasilkan bau yang kurang sedap, sehingga dapat menimbulkan penyakit. Berdasarkan hal tersebut, manajemen bank sampah perlu dikembangkan agar masyarakat mampu mengelola sampah dengan baik. Serta mampu memilah-milah mana sampah yang bisa didaur ulang dan mana sampah yang tidak bisa didaur ulang.

Dengan adanya permaslahan sampah tersebut, tidak heran jika sampah menjadi masalah bagi pemerintah baik daerah maupun pusat juga masyarakat pada umumnya. Oleh sebab itu pemerintah berupaya agar masyarakat dapat membentuk organisasi atau lembaga yang berupa Bank dan Koperasi agar dapat dijadikan solusi dalam mengelola sampah.

Konsep Bank Sampah pada dasarnya mengadopsi konsep bank pada umumnya. Terdapat transaksi menabung dan menarik dana dari sebuah bank. objek yang ditabung 
adalah sampah anorganik dan organik. Pada prosesnya masyarakat datang menabung sampah, dan pada waktu yang telah ditentukan, kemudian dapat menarik uang dari sampah yang telah ditabung oleh masyarakat tersebut. Dalam hal ini Bank sampah "Alam Lestari" di desa Ngasinan Etan menentukan pada minggu keempat (ke-4) atau sebulan sekali, yang diketuai oleh ibu RW bernama Sri Supadmi dengan wakil ketua Susma Suryani. Bank sampah "Alam Lestari” dilakukan di halaman rumah bapak Sugimin.

Serupa dengan bank pada umumnya, Bank Sampah "Alam Lestari" juga memerlukan pengelolaan yang bersifat professional baik dari sisi pelayanan terhadap nasabah (eksternal) maupun pengelolaan manajemen internal Bank Sampah. Bank sampah "Alam Lestari" dibentuk berdasarkan kesadaran masyarakat untuk turut berperan aktif mengatasi permasalahan pengelolaan sampah yang yang ada didesa Ngasinan Etan. Salah satu ide dasar yang membangun konsep "Bank sampah Alam Lestari" adalah mengurangi volume sampah yang dibuang disungai. Saat ini konsep "Bank Sampah Alam Lestari" sudah mulai banyak bertumbuh dan berkembang sebagai komunitas masyarakat, salah satunya bank sampah di Desa Ngasinan Etan Keluarahan Gebang Kecamatan Masaran Kabupaten Sragen.

Permasalahan utama yang dihadapi oleh Bank Sampah "Alam Lestari” di desa Ngasinan Etan adalah masih ada kesan malu dari masyarakat untuk datang menabung sampah. Pencatatan transaksi kas masuk dan keluar masih manual, pegawai dan pengurus bank sampah Ngasinan Etan adalah anggota masyarakat, sehingga untuk menyelesaikan transaksi dalam bentuk laporan penjualan terkadang dibawa ke rumah, dan dikerjakan jika ada waktu luang. Hal ini tentunya akan menghambat kepercayaan masyrakat akan proses transaksi yang dilakukan oleh bank sampah Ngasinan Etan dalam menyajikan laporan penjualannya. Dari penjelasan di atas, maka dapat disimpulkan permasalahan focus pada pengelolaan manajemen bank sampah agar semua transaksi dapat diselesaikan pada saat kegiatan berlangsung, serta pencatatan keuangan dapat terekam dengan benar dan tepat waktu.

Tujuan pendirian dari bank sampah "Alam Lestari" di desa Ngasinan Etan adalah untuk melakukan edukasi kepada masyarakat desa Ngasinan Etan untuk menjaga kesehatan lingkungan. Kegiatannya meliputi 5M, yaitu mengurangi sampah, memilah sampah, memanfaatkan sampah, mendaur ulang sampah, dan menabung sampah. Bank Sampah "Alam Lestari” Ngasinan Etan selain menerima tabungan sampah berupa sampah anorganik. Saat menerima tabungan sampah dari nasabah, sampah ditimbang dan dicatat dalam buku tabungan nasabah. Di dalam buku tabungan, tertera berat sampah maupun rupiah yang diperoleh.

Bank sampah "Alam Lestari” di desa Ngasinan Etan dibentuk pada tanggal 23 Februari 2020. Hal ini masih tergolong baru, sehingga masih banyak yang perlu dipelajari dalam pengelolaan manajemen bank sampah "Alam Lestari". Dengan adanya permasalahan ini, diharapkan tim Pengabdian Kepada Masyarakat dapat mendampingi manajemen bank sampah "Alam Lestari" di desa Ngasinan Etan agar dapat berjalan dengan baik dan manajemen dapat dikelola dengan baik.

Manfaat dari kegiatan Pengabdian Kepada Masyarakat ini adalah sebagai berikut:

1. Dengan dilakukan pengabdian ini diharapkan pihak manajemen bank sampah "Alam Lestari" dapat memahami prosedur atau proses pengelolaan bank sampah dengan baik dan benar.

2. Dengan dilakukan pengabdian ini diharapkan pihak manajemen bank sampah "Alam Lestari" dapat mengetahui cara pencatatan keuangan secara sederhana.

3. Mampu memberikan pengetahuan yang luas tentang pemahaman pengelolaan manajemen operasional dan keuangan dan membantu meningkatkan kualitas SDM khususnya penduduk di desa Ngasinan Etan. 


\section{METODE PENGABDIAN}

Penyampaian materi dalam pelaksanaan pengabdian kepada masyarakat ini adalah dengan metode:

1. Metode yang digunakan adalah dengan memberikan penjelasan atau materi tentang pembuatan laporan keuangan.

2. Praktek simulasi membuat atau mencatat laporan keuangan sederhana.

3. Membuat pencatatan kas masuk dan kas keluar.

4. Tanya jawab yang mengarah pada diskusi

5. Pemecahan berbagai masalah yang dihadapi.

Bentuk kegiatan pengabdian masyarakat ini adalah sebagi berikut:

1. Penyuluhan dan diskusi. Pada tahap ini khalayak sasaran secara bersama-sama diberi penyuluhan tentang materi-materi yang berhubungan dengan proses operasional manajemen bank sampah.

2. Pendampingan manajemen dalam mencetak laporan keuangan secara sederhan.

3. Mengevaluasi kegiatan program.

\section{HASIL DAN PEMBAHASAN}

Metode penyelesaian untuk mengatasi permasalah di atas yaitu dengan memberikan contoh gambaran manajemen alur pengelolaan bank sampah serta pengetahuan tentang cara pembukuan keuangan sederhana dalam mencatat semua aktivitas keuangan yang sudah dilakukan.

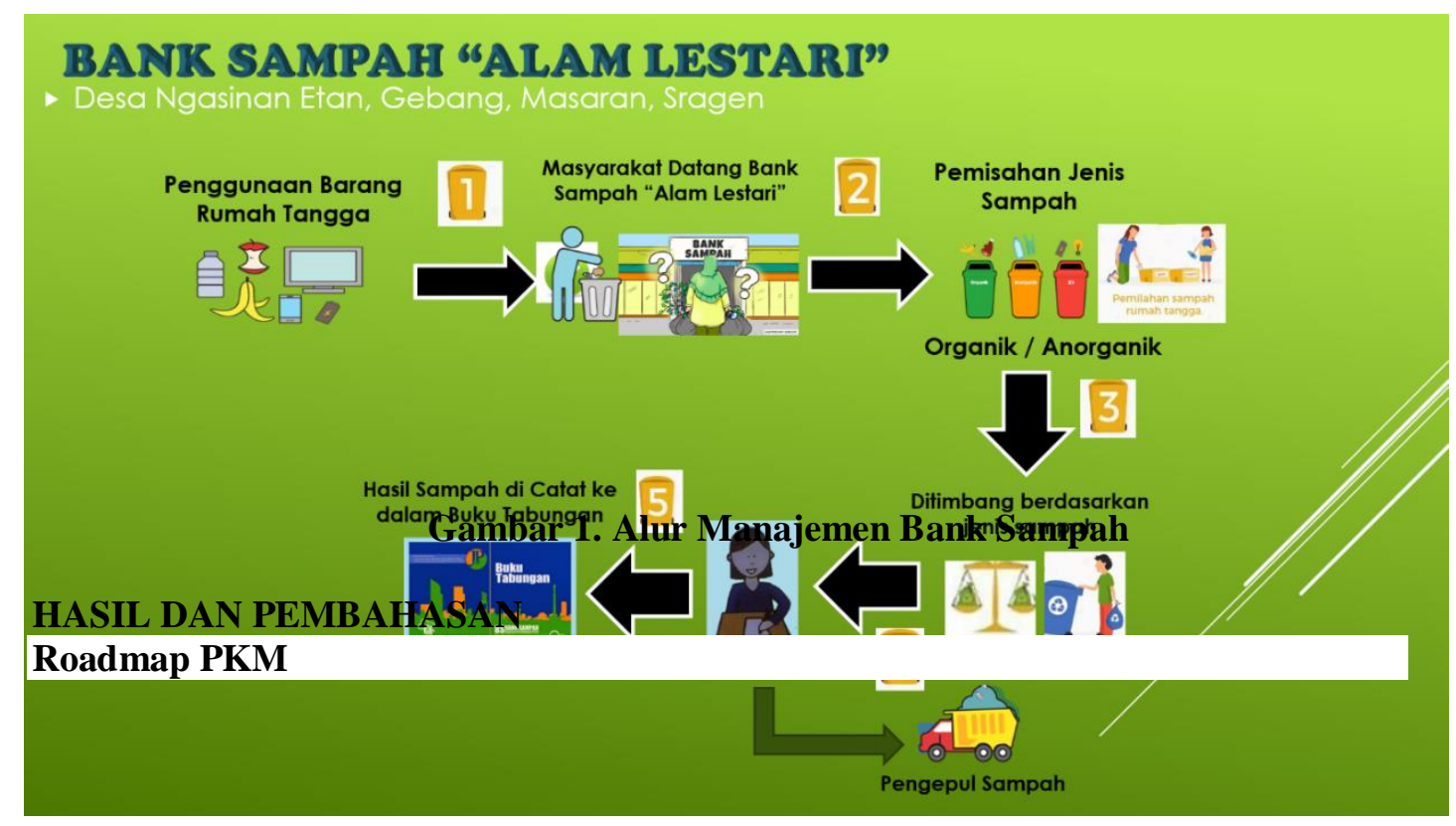




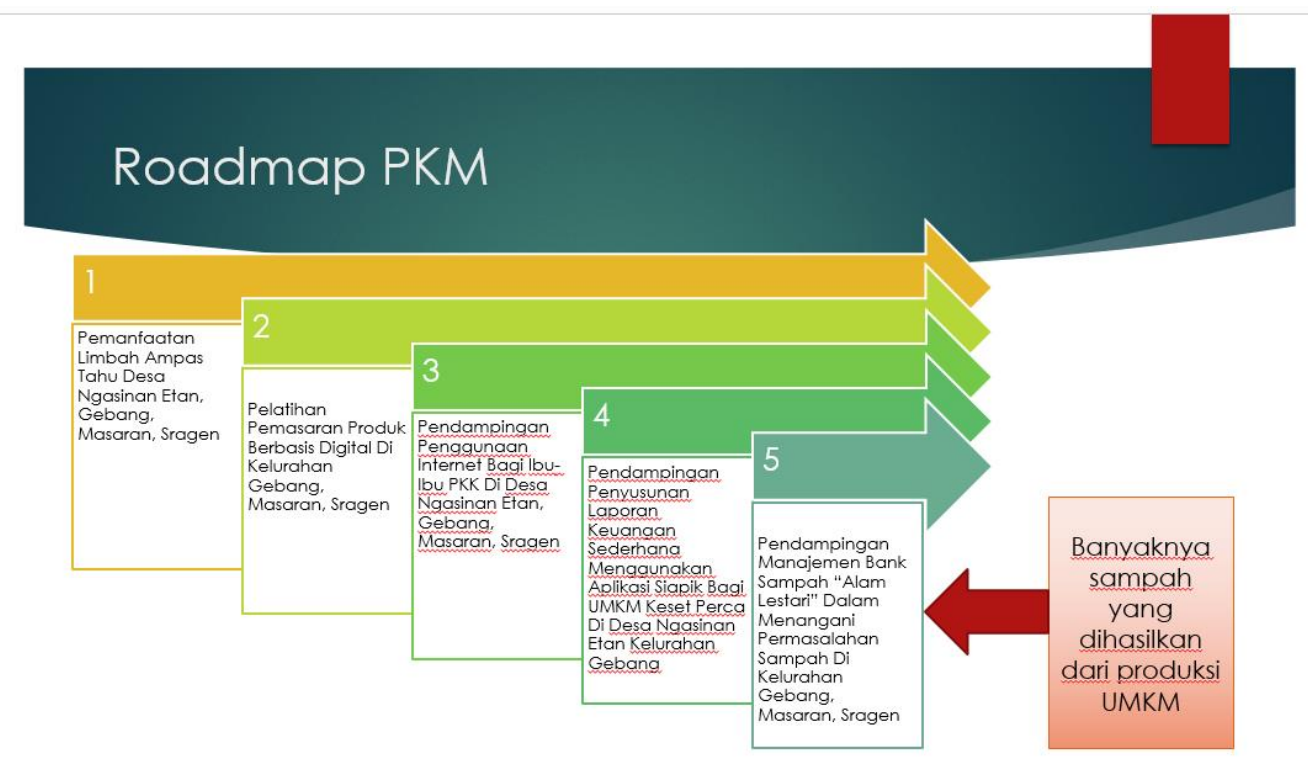

\section{Memahami Pengertian Laporan Keuangan}

1. Laporan Keuangan perusahaan disusun sebagai bentuk pertanggungjawaban manajemen terhadap pihak-pihak yang berkepentingan dengan kinerja perusahaan yang dicapai selama periode tertentu.

2. Bagi pihak intern dan ekstern perusahaan, Laporan Keuangan digunakan sebagai alat untuk memahami kondisi keuangan perusahaan untuk keperluan pengambilan keputusan keuangan.

3. Dalam hal ini, manajemen hanya perlu mencatat antara uang masuk dan uang keluar, guna mencatat semua transaksi yang terjadi pada hari tersebut

\section{Pelatihan Pencatatan Pembukuan}

Siapkan data atau buku pada masing-masing kelompok atau peserta yang mengikuti kegiatan bank sampah. Usahakan satu orang memiliki satu buku catatan tersendiri. Agar panitia mudah dalam mengevaluasi pendapatan dari setiap anggota kelompok.

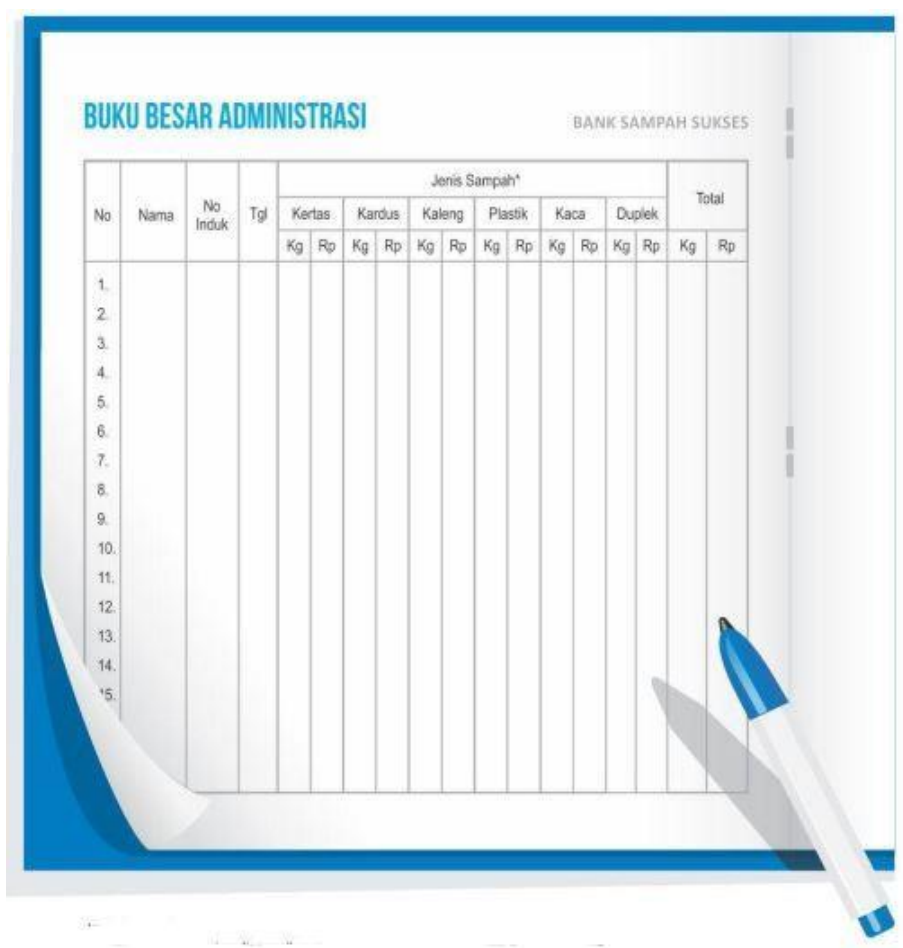

Contoh jurnal dan buku besar untuk kegiatan beroperasi lebih dari satu periode akuntansi 
Wasana Nyata: Jurnal Pengabdian Pada Masyarakat

Vol 5 , No $1(2021) ; 1-9$

ISSN : 2747-2876 (cetak)

ISSN : 2580-8443 (online)

Rekap Semua Data di Dalam Ms. Exel

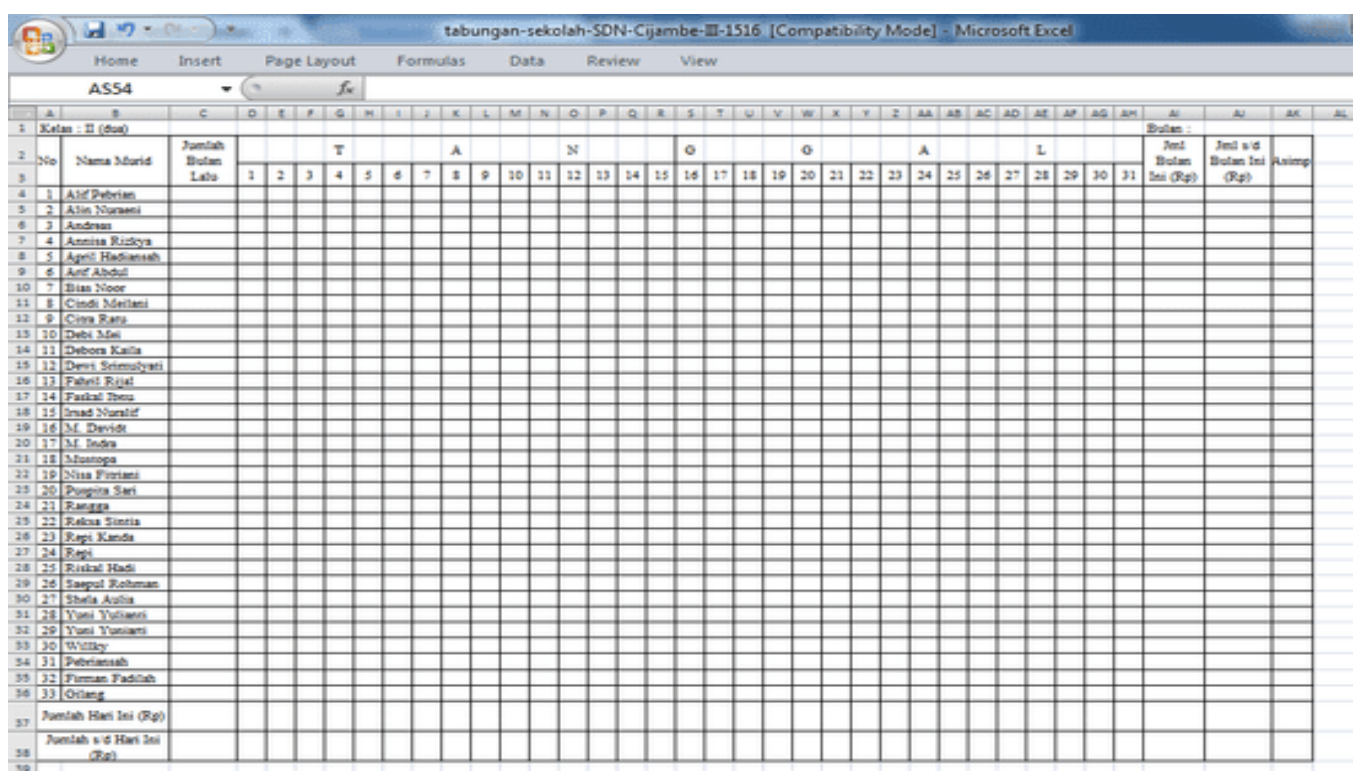

Dalam hal ini, kegiatan Bank Sampah dapat mencatat laporan tabungan sebagai berikut:

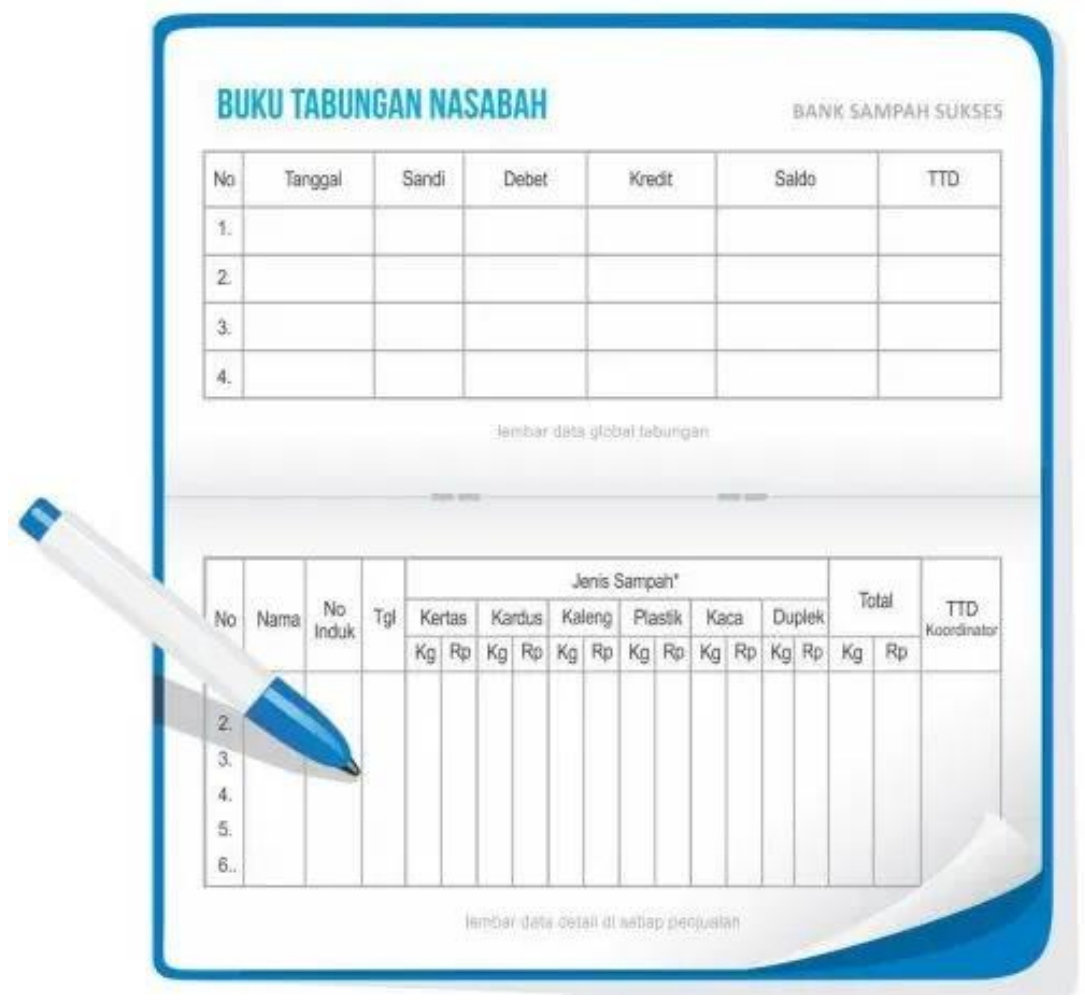


Wasana Nyata: Jurnal Pengabdian Pada Masyarakat

Vol 5, No 1 (2021) ; $1-9$

Buku Pencatatan Kas Msuk dan Kas Keluar

\begin{tabular}{|l|l|l|l|l}
\hline \hline \multirow{3}{*}{ Tanggal } & \multicolumn{2}{|c|}{ Tabungan } & Jumlah & Tanda \\
\cline { 2 - 4 } & $\begin{array}{c}\text { Keluar } \\
\text { Rp. }\end{array}$ & $\begin{array}{l}\text { Masuk } \\
\text { Rp. }\end{array}$ & $\begin{array}{c}\text { Tang. } \\
\text { Rangan }\end{array}$ \\
\hline & & & & \\
\hline & & & & \\
\hline & & & & \\
\hline & & & & \\
\hline & & & & \\
\hline & & & & \\
\hline & & & & \\
\hline & & & & \\
\hline & & & & \\
\hline & & & & \\
\hline & & & & \\
\hline & & & & \\
\hline & & & & \\
\hline & & & & \\
\hline & & & & \\
\hline & & & & \\
\hline
\end{tabular}

Rekap Kebutuhan Buku Pencatatan yang diperlukan

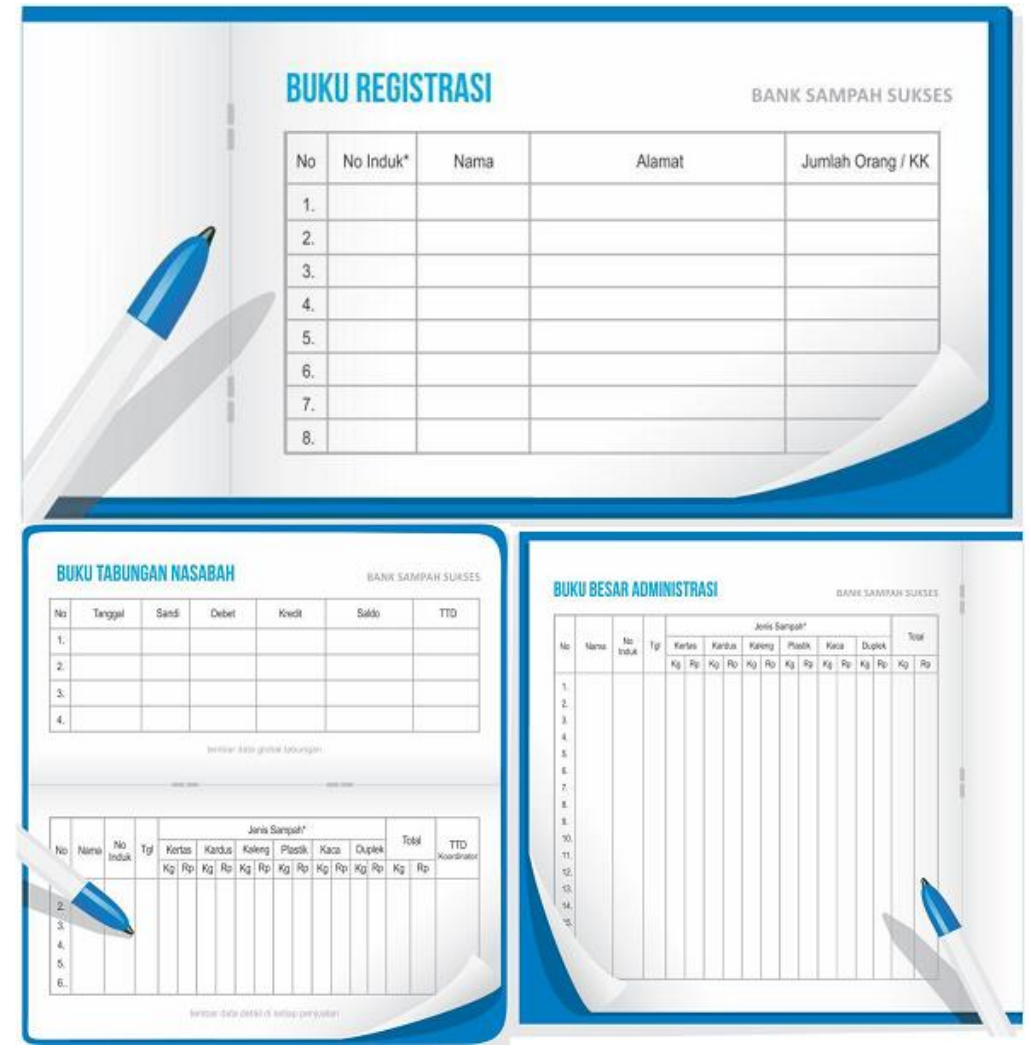




\section{Pelaksanaan Pengabdian Kepada Masyarakat}

Dimasa pandemic covid-19 ini membuat kegiatan Pengabdian Kepada Masyarakat dilakukan secara online. Dengan menggunakan aplikasi zoom, maka kegiatan Pengabdian Kepada Masyarakat ini dapat berjalan dengan lancar.
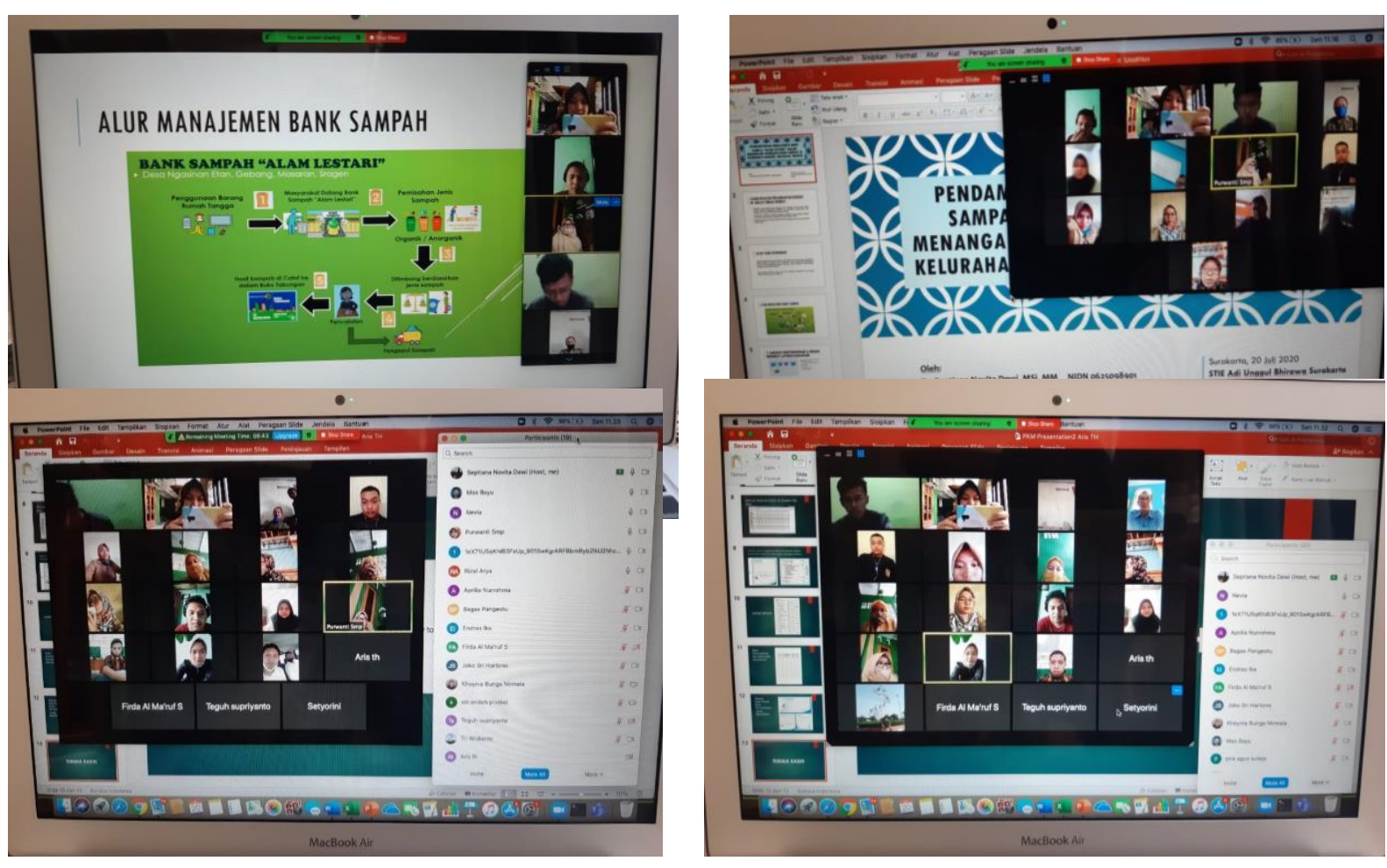

\section{SIMPULAN}

Kesimpulan pelaksanaan pengabdian kepada masyarakat ini adalah:

1. Dengan dilakukan pengabdian ini pihak manajemen bank sampah "Alam Lestari" dapat memahami prosedur atau proses pengelolaan bank sampah dengan baik dan benar.

2. Dengan dilakukan pengabdian ini pihak manajemen bank sampah "Alam Lestari" dapat mengetahui cara pencatatan keuangan secara sederhana.

3. manajemen bank sampah "Alam Lestari" mampu memahami tentang pengelolaan manajemen operasional dan keuangan dan membantu meningkatkan kualitas SDM khususnya penduduk di desa Ngasinan Etan.

\section{SARAN}

Pengabdian masyarakat ini diharapkan dapat dilakukan secara kesinambungan, setelah melakukan pengabdian tentang pencatatan laporan keuangan secara sederhana dan mudah dipahami, diharapkan selanjutnya dapat meningkatkan penyusunan laporan keuangan secara tertip dan mampu menghasilkan laporan keuangan pada setiap bulannya. 


\section{DAFTAR PUSTAKA}

Haryanto, Dewi, Riyadi, 2020. Pemanfaatan Limbah Ampas Tahu Menjadi Produk Pangan Di Desa Ngasinan Etan, Gebang Masaran, Sragen. Adi Widya: Jurnal Pengabdian Kepada Masyarakat Vol 4 No. 1 (2020)

Khristiana, Dewi \& Widiyanto, 2020. Pelatihan Pembuatan Laporan Keuangan Sederhana Pada Petani Jahe Merah Di Baturetno. Wasana Nyata : Jurnal Pengabdian kepada Masyarakat ISSN : 2580-8443 (online) Vol.4, No.1 April (2020) ; p.57- 63

Suryani, 2014. Peran Bank Sampah Dalam Efektivitas Pengelolaan Sampah (Studi Kasus Bank Sampah Malang). Aspirasi Vol. 5 No. 1, Juni 2014

Yulianti \& Huda, 2018. Manajemen Pengelolaan Sampah Studi Kasus di Bank Sampah Tirtarona Tlogomas Kota Malang. JPM (Jurnal Pemberdayaan Masyarakat) ISSN : 25411977 E-ISSN : 25411977 Vol. 3 No. 22018 